\title{
Dynamics of kimberlite pipe formation: insights from the B/K9 kimberlite (Orapa, Botswana)
}

\author{
B. Buse ${ }^{1}$, M. Field ${ }^{2}$, J. Schumacher ${ }^{1}$, R.S.J. Sparks ${ }^{1}$, K. Chisi ${ }^{3}$ and T. Tlhaodi ${ }^{3}$ \\ ${ }^{I}$ Department of Earth Sciences, University of Bristol, Bristol, UK (ben.buse@bristol.ac.uk) \\ ${ }^{2}$ DiaKim Consulting Limited, Mayfield Wells Road, Wookey Hole, Wells, UK \\ ${ }^{3}$ Geology Department, Debswana Orapa, Lethakane \& Damtshaa Mines, Orapa, Botswana
}

\section{Introduction}

Geological mapping of the B/K9 kimberlite (Orapa, Botswana) has provided insights into pipe formation. The B/K9 kimberlite forms part of a cluster of over 50 kimberlites of Cretaceous age (ca. $90 \mathrm{Ma}$ ). It was intruded through Archaean granite-gneisses into the overlying Permian-Jurassic Karroo Supergroup, which consists of mudstones overlain by sandstones (Ntane Formation) and basalts (Stormberg Formation, ca. 180 Ma) (Field \& Scott Smith, 1999; Key \& Ayres, 2000). We present the findings of an ongoing geological investigation into the $\mathrm{B} / \mathrm{K} 9$ kimberlite and propose a model for its formation, based upon the four-stage eruption model proposed by Sparks et al. (2006).

\section{The geology of $\mathrm{B} / \mathrm{K} 9$}

The $\mathrm{B} / \mathrm{K} 9$ kimberlite consists of three coalesced pipes (north, central and south) (Fig. 1). The north and south pipes consist of pipe-filling bodies of coherent kimberlite $(\mathrm{CK})$, commonly referred to as hypabyssal kimberlite. In the central pipe the kimberlite is overlain by epiclastic deposits.

Basalt forms the country rock at the present level of exposure, and dips gently into the pipe. Basalt joint planes form the contacts between the pipe and the wallrock, and they dip steeply away from the pipe. Adjacent to the basalt, the $\mathrm{CK}$ is deformed and clast fabrics steepen sharply towards the contact. The basalt contains veins of peperite, which consist of fine sandstone and sparse kimberlite minerals including olivine.

$\mathrm{CK}$ is a dark competent rock, which consists of pseudomorphed olivine and phlogopite macrocrysts and phenocrysts, oxide-serpentine groundmass and calcite or serpentine patches. The CK displays textures which range from globular, were the crystals are rimmed by groundmass with interstitial calcite or serpentine patches, to uniform, which is almost devoid

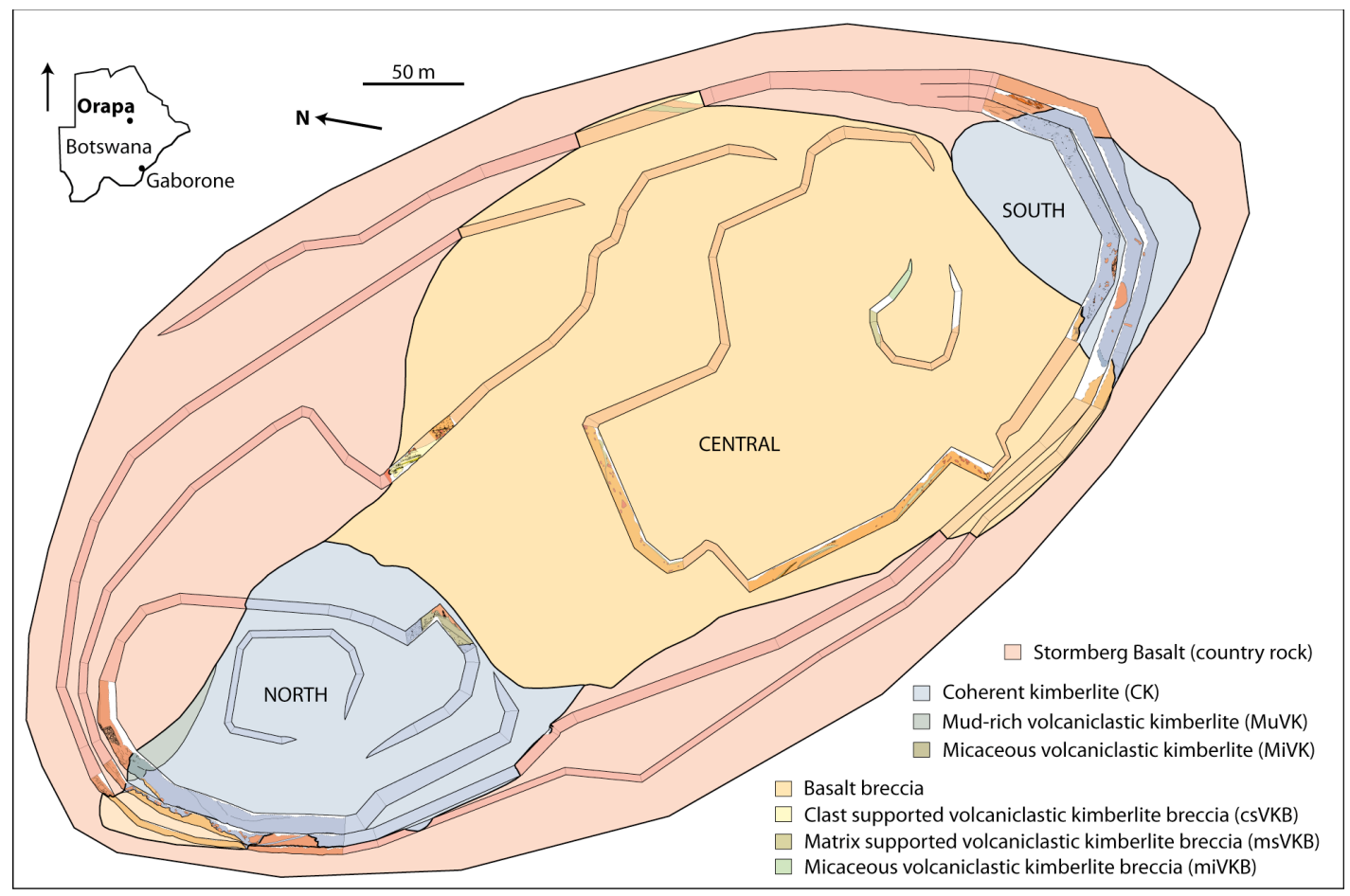

Figure 1. Geological map of the B/K9 kimberlite 

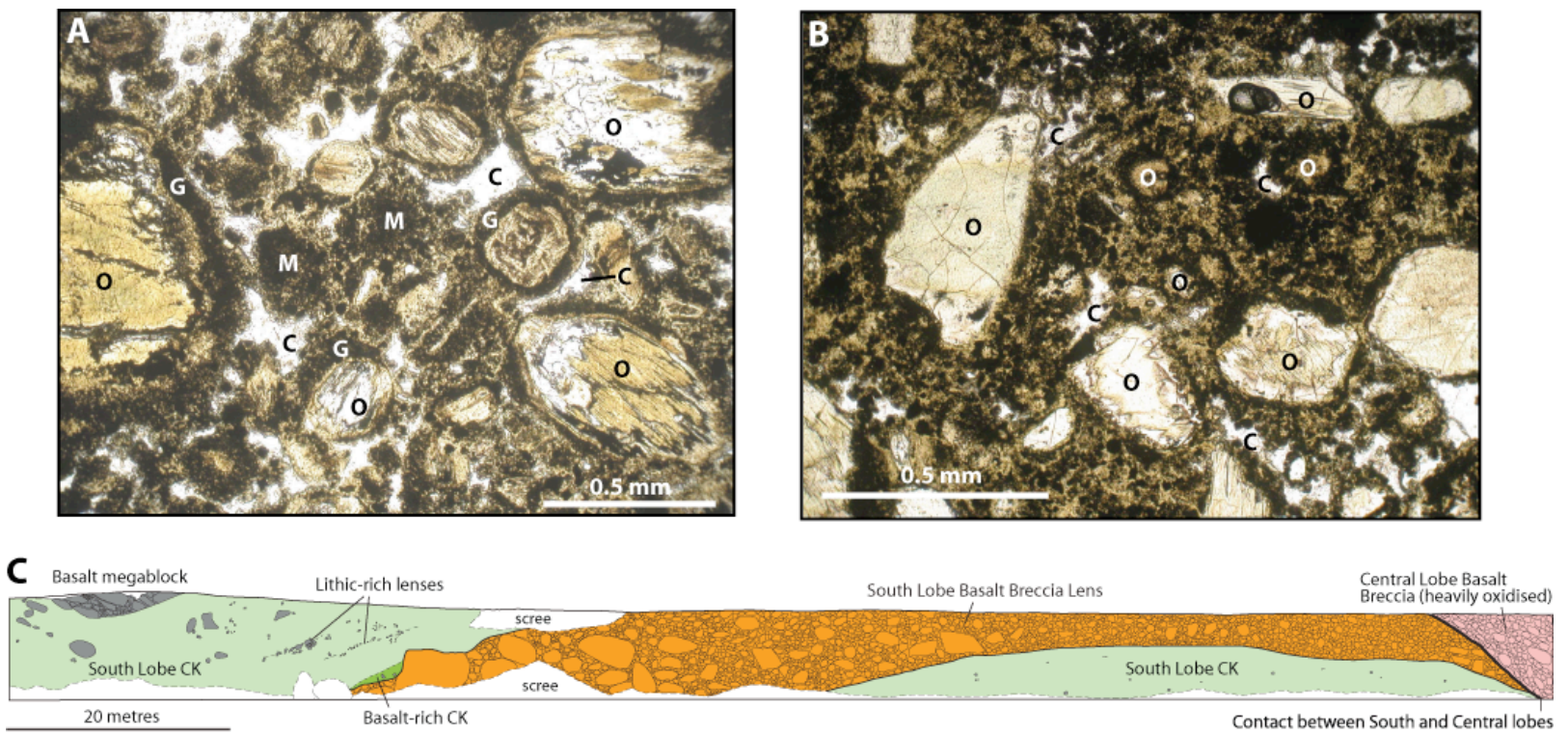

Figure 2: A \& B) Photomicrographs showing the different textures of CK: A) Globular-textured CK with olivine macrocrysts and phenocrysts (o) rimmed by oxide-serpentine groundmass (g) with interstitial calcite patches (c); B) Uniform-textured CK with olivine macrocrysts and phenocrysts (o) surrounded by groundmass, with rare interstitial calcite patches (c). C) Bench map of the NW margin of the south pipe, showing marginal basalt breccia lenses, lithic-rich lenses and basalt megablocks

of interstitial patches with groundmass ubiquitous between the crystals (Fig. 2 a \& b). The CK contains small $(<10 \mathrm{~cm})$ dispersed lithic clasts $(2-7 \%)$, which are predominantly basalt in composition or peridotite, with no sandstone, mudstone or basement clasts observed. At the margins of the pipe-filling $\mathrm{CK}$ are large basalt blocks $(0.5-12 \mathrm{~m})$, lithic-rich lenses and basalt breccia lenses, which dip into the pipe (Fig. 2 c).

Associated with the serpentinization of the kimberlite, are two minerals, rarely observed within kimberlites, hydrogarnet and bultfonteinite (Stripp et al., 2006; Ckakhmouradian \& Mitchell, 2001). Hydrogarnet is present within the oxide-serpentine groundmass and partially replaces titanomagnetite. It also occurs within basalt xenoliths intergrowth with serpentine or replacing bultfonteinite. Bultfonteinite is restricted to the basalt xenoliths and replaces plagioclase.

The epiclastic deposits consist of three lithofacies: basalt breccia, which is the dominant lithofacies and forms poorly sorted, clast-supported debris avalanche deposits; matrix-supported volcaniclastic kimberlite breccia (msVKB), which forms poorly-sorted debris flow deposits; and clast-supported volcaniclastic kimberlite breccia (csVKB), which forms well-sorted, bedded, granular flow deposits. The csVKB consists of alternating lithic-rich and lithic-poor layers, which dip steeply into the pipe $\left(30^{\circ}\right)$, at the angle of repose.

\section{Interpretation}

The features observed within the basalt country rock, suggest that post eruption it has partially collapsed, disintegrating into megablocks and subsiding into the pipe, to deform the adjacent kimberlite. The peperite veins can be accounted for by the interaction of ascending kimberlite magma with the Ntane sandstone aquifer. The removal of the Ntane sandstone as peperite may have facilitated the partial collapse of the overlying basalt.

The CK is consistent with a welded pyroclastic deposit, emplaced as an aggrading fluidised bed. The pyroclastic material is fluidised as it accumulates within the pipe, by the continued eruption of gas and pyroclasts though it. A fluidised system allows the incorporation and mixing of wall-rock material with juvenile material, to produce a deposit with dispersed lithic clasts. Fluidisation within tapered conduits has been experimentally shown to produce inward dipping layers (Gernon et al., 2007) and allows large basalt blocks to sink towards the centre of the pipe. The microscopic textures can be explained by varying degrees of welding, with the globular textures, resulting from incipient welding (sintering at point contacts) and the uniform textures from intense welding (resulting in the loss of clast outlines). Welding will occur when gas velocities, within the pipe, fall below a critical level leading to the agglutination of particles and the termination of fluidisation (Brown et al., 2008).

The growth of hydrogarnet and bultfonteinite is consistent with low temperature post-emplacement alteration, for they are stable at temperatures of 350$250^{\circ} \mathrm{C}$, which is comparable to the temperatures estimated for serpentinization (Stripp et al., 2006).

\section{Model of pipe formation}

Based upon the fieldwork, we propose a model for the pipe's formation, involving the following stages (Fig. 3). (1) Ascending magma interacts with the Ntane 


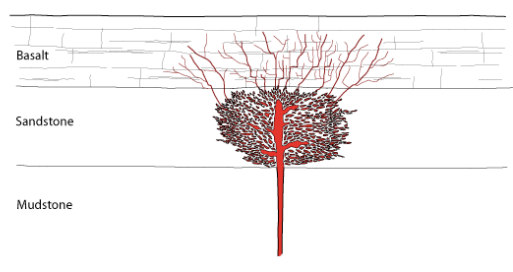

(A) Magma ascent and peperite formation

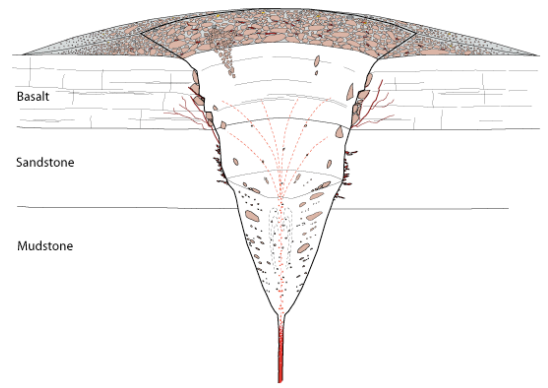

(D) Pipe infilling - aggrading fluidised bed

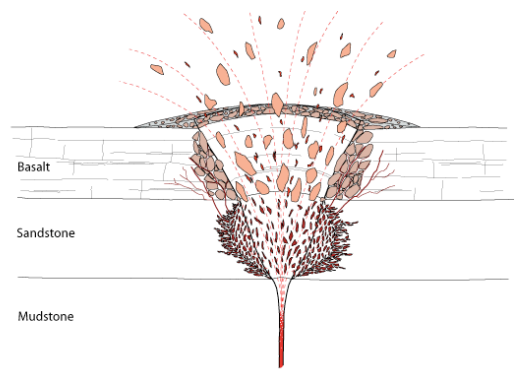

(B) Crater forming explosions

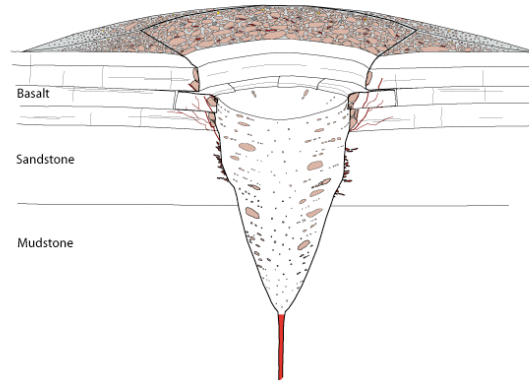

(E) Post eruption basalt collapse
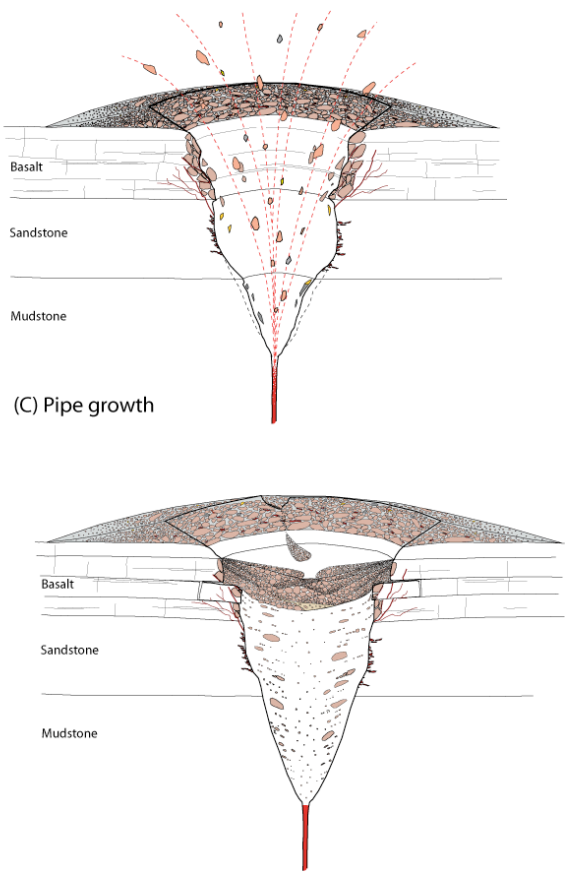

(F) Epiclastic processes fill crater

Figure 3. A model of pipe formation, specifically for the B/K9 kimberlite, but with implications for regions' kimberlite pipes. Stage G, hydrothermal alteration, is not shown.

sandstone to produce peperite. The peperite explosively expands, fracturing and injecting into the overlying Stormberg basalt. (2) Crater forming explosions follow, ejecting the peperite and the overlying basalt. (3) Continued eruption and pipe-wall collapse result in pipe growth. (4) Material begins to accumulate within the pipe, as the eruption wanes, and is fluidised by the eruption of gas and pyroclasts through it. Coeval collapses feed material into the aggrading fluidised bed. (5) Post eruption, the deposit welds and basalt blocks slide into the pipe, deforming and supported by the adjacent kimberlite. (6) Epiclastic processes fill any empty space within the upper parts of the pipe. (7) The deposit cools and is hydrothermally altered by the circulation of meteoric fluids. This model is important for understanding the regions' kimberlite pipes, for peperite formation may be a common process as a consequence of the regional aquifer.

\section{Acknowledgments}

This research is supported by a NERC-CASE (De Beers) studentship awarded at the University of Bristol.

\section{References}

Brown, R. J., Buse, B., Sparks, R. S. J., \& Field, M., 2008.

On the Welding of Pyroclasts from Very Low

Viscosity Magmas: examples from Kimberlite

Volcanoes. Geology, (in press).
Ckakhmouradian, A. R., \& Mitchell, R. H., 2001. Three compositional varieties of perovskite from kimberlites of the Lac de Gras field (Northwest Territories, Canada). Mineralogical Magazine 65 (1), 133-148.

Field, M., \& Scott Smith, B. H., 1999. Contrasting Geology and Near-Surface Emplacement of Kimberlite Pipes in Southern Africa and Canada. Proceedings of the Seventh International Kimberlite Conference $1,214-237$.

Gernon, T. M., Gilbertson, M. A., Sparks, R. S. J., \& Field, M., 2007. Tapered fluidized beds and the role of fluidization in mineral emplacement. In Berruti, F., Bi, X., \& Pugsley, T. (Eds.), Fluidization XII: New Horizons in Fluidization Engineering, RP4, 545552

Key, R. M., \& Ayres, N., 2000. The 1998 edition of the National Geological Map of Botswana. Journal of African Earth Sciences 30 (3), 427-451.

Sparks, R. S. J., Baker, L., Brown, R. J., Field, M., Schumacher, J., Stripp, G., et al., 2006. Dynamical constraints on kimberlite volcanism. Journal of Volcanology and Geothermal Research 155 (1-2), 18-48.

Stripp, G. R., Field, M., Schumacher, J. C., Sparks, R. S. J., \& Cressey, G., 2006. Post-emplacement serpentinization and related hydrothermal metamorphism in a kimberlite from Venetia, South Africa. Journal of Metamorphic Geology 24 (6), 515-534. 